\title{
Pengembangan Modul Matematika Terintegrasi Nilai-Nilai Keislaman Melalui Pendekatan Realistic Mathematics Education (RME) di Propinsi Riau
}

\author{
Suci Yuniati', Arnida Sari² \\ 1,2 Prodi Pendidikan Matematika, Fakultas Tarbiyah dan Keguruan \\ UIN Sultan Syarif Kasim Riau, \\ Jl. HR. Soebrantas Km. 15 Tampan Pekanbaru, Indonesia \\ a)E-mail: arnidasari@uin-suska.ac.id
}

\begin{abstract}
ABSTRAK
Penelitian ini bertujuan untuk mengembangkan modul matematika yang terintegrasi nilainilai keislaman melalui pendekatan Realistic Mathematics Education (RME) pada mata pelajaran matematika untuk Madrasah Tsanawiyah (MTs) Al-Munawwarah Pekanbaru dan MTs Negeri Danau Bingkuang Kampar. Model pengembangan yang digunakan adalah ADDIE. Pengambilan data dalam penelitian ini menggunakan kuesioner atau angket. Hasil perhitungan data hasil uji validitas oleh ahli teknologi pendidikan memperoleh Persentasi keidealan 85,19 dan oleh ahli materi pembelajaran memperoleh 86,42, serta penilaian praktikalitas pada saat uji coba memperoleh 84,14. Data tersebut menunjukkan bahwa modul matematika yang terintegrasi nilai-nilai keislaman melalui pendekatan Realistic Mathematics Education (RME) yang dikembangkan layak dan praktis untuk digunakan oleh siswa.
\end{abstract}

Kata Kunci : modul, nilai-nilai keislaman, RME

\begin{abstract}
This research aims to develop a mathematics module that integrates Islamic values through realistic mathematics education approaches in mathematics subjects for Madrasah Tsanawiyah (MTs) Al-Munawwarah Pekanbaru and MTs domestic Danau Bingkuang Kampar. The development model used is ADDIE. Taking data in this study using questionnaires or questionnaires. The result of data calculation result of validity test by technological technologist get percentage ideal 85,19 and by learning material subject get 86,42 and valuation of practicality at the time of trial get 84,14. These data indicate that the mathematical module that integrates Islamic values through a realistic mathematics education (RME) approach developed is feasible and practical for use by students.
\end{abstract}




\section{PENDAHULUAN}

Kemajuan siswa dalam pembelajaran ditandai dengan adanya hasil belajar yang baik dari siswa yang telah menerima pengalaman belajar. Dalam pembelajaran matematika, hasil belajar siswa merupakan salah satu aspek yang patut diperhatikan sehingga bisa menjadi informasi bagi guru tentang keberhasilan siswa selama proses pembelajaran melalui kegiatan belajar.

Proses pembelajaran dikatakan efektif apabila siswa dilibatkan langsung secara aktif untuk berusaha dan mencari pengalaman serta menghubungkan informasi yang diperolehnya tentang matematika. Dalam proses pembelajaran, guru perlu juga memfasilitasi serangkaian kegiatan yang memberi ruang bagi siswa untuk terjadinya interaksi sosial. Siswa terlibat langsung secara aktif dalam membangun makna matematika bagi dirinya, baik secara individual maupun kelompok. Ada beberapa faktor yang mempengaruhi kemampuan pemecahan masalah matematika antara lain adalah kreativitas dan kecerdasan emosional (Hartati,dkk, 2017)

Fakta di lapangan menunjukkan bahwa proses pembelajaran di kelas cenderung berlangsung secara teoritis. Situasi tersebut berdampak pada siswa yang cenderung menghafal dan menganggap bahwa matematika adalah suatu masalah yang besar ketika siswa dihadapkan pada materi yang sangat sulit. Sesuai dengan pendapat Rahayu (2016) tentang kesulitan belajar matematika bagi siswa, terutama jika sudah tertanam sejak mereka duduk di sekolah dasar. Selain itu, siswa tidak menemukan suatu konsep untuk memahami materi yang diajarkan, akibatnya sesuatu yang dipahami oleh siswa hanyalah bersifat sementara. Hal ini membuktikan bahwa pemahaman siswa terhadap konsep-konsep yang dipelajari belum tercapai, sehingga menyebabkan pembelajaran menjadi tidak efektif dan bermuara pada rendahnya persentase ketuntasan belajar. Dari sisi lain matematika sebagai ilmu pengetahuan yang bersifat abstrak, menyebabkan siswa tidak tertarik untuk mempelajari bahkan dianggap sebagai mata pelajaran yang paling membosankan. Sebagai akibat dari kondisi seperti itu maka hasil belajar matematika di sekolah-sekolah, baik di sekolah dasar maupun di sekolah menengah masih relatif rendah dibandingkan dengan hasil belajar siswa untuk bidang studi yang lain.

Selain itu yang menjadi salah satu faktor rendahnya hasil belajar siswa adalah guru masih menggunakan buku-buku atau bahan ajar cetak konvensional. Guru hanya menggunakan sebuah buku sebagai satusatunya bahan ajar. Bahan ajar cetak tersebut hanya berisi ringkasan materi, contoh soal dan latihan-latihan soal dalam pembelajaran matematika. Strategi pengorganisasian dan penyampaian isi di dalam bahan ajar tersebut tidak terstruktur dengan baik dan kemasannya sangat tidak menarik. Materi yang disajikan di dalam bahan ajar cetak tersebut banyak yang bersifat abstrak dan rumit sehingga siswa enggan untuk membacanya apalagi mempelajarinya. Selain itu, guru dalam kegiatan pembelajaran matematika di kelas didapatkan bahwa, materi ajar yang tersaji di dalam bahan ajar tersebut tidak pernah dikaitkan dengan objek- objek atau kejadian-kejadian aktual di dunia nyata yang akrab dengan siswa. Materi ajar yang disajikan hanya berupa definisi dari suatu konsep, sekumpulan rumus- rumus, contoh soal, dan latihan soal. Permasalahan-permasalahan yang disajikan di dalam bahan ajar tersebut juga bersifat akademis semata. Permasalahan yang disajikan mengandung objek dan kejadian yang diidealkan yang tidak memiliki kaitan dengan realitas siswa. Penggunaan bahan ajar khususnya bahan ajar yang berupa bahan cetak seperti modul belum banyak digunakan. 
Menurut Houston dan Howson (Wena, 2011) modul pembelajaran meliputi seperangkat aktivitas yang bertujuan mempermudah siswa untuk mencapai seperangkat tujuan pembelajaran. Modul mempunyai self contained, yang artinya pengemasan modul dalam satu kesatuan yang utuh untuk mencapai kompetensi tertentu. Modul juga memiliki sifat membantu dan mendorong pembacanya untuk mampu membelajarkan diri sendiri dan tidak bergantung pada media lain.

Secara garis besar penyusunan modul atau pengembangan modul dapat mengikuti langkah-langkah sebagai berikut: 1) Merumuskan sejumlah tujuan secara jelas, spesifik, dalam bentuk kelakuan siswa yang dapat diamati dan diukur, 2) Urutan tujuantujuan itu yang menentukan langkah-langkah yang diikuti dalam modul itu, 3) Test diagnostik untuk mengukur latar belakang siswa, pengetahuan dan kemampuan yang telah dimilikinya sebagai pra-syarat untuk menempuh modul itu, 4) Menyusun alasan atau rasional pentingnya modul ini bagi siswa. Siswa harus tahu apa gunanya mempelajari modul tersebut, 5) Kegiatankegiatan belajar direncanakan untuk membantu dan membimbing siswa agar mencapai kompetensi-kompetensi seperti dirumuskan dalam tujuan, dan 6) Menyusun post-test untuk mengukur hasil belajar siswa, hingga manakah siswa yang menguasai tujuan-tujuan modul (Nasution, 2011).

Keuntungan yang diperoleh dari pembelajaran dengan penerapan modul adalah sebagai berikut: 1) meningkatkan motivasi siswa, karena setiap kali mengerjakan tugas pelajaran yang dibatasi dengan jelas dan sesuai dengan kemampuan; 2) setelah dilakukan evaluasi, guru dan siswa mengetahui benar, pada modul yang mana siswa telah berhasil dan pada bagian modul yang mana mereka belum berhasil; 3) siswa mencapai hasil sesuai dengan kemampuannya; 4) bahan pelajaran terbagi lebih merata dalam satu semester; dan 5) pendidikan lebih berdaya guna, karena bahan pelajaran disusun menurut jenjang akademik (Somayasa, 2013).

Dengan melihat keuntungan dari penggunaan modul, sehingga peneliti mencoba mengembangkan modul matematika yang terintegrasi nilai-nilai keislaman.

Nilai islam merupakan nilai yang bersumber langsung dari Al-Qur'an dan Hadits memiliki arti penting dalam pendidikan nilai, terutama bagi umat muslim. Nilai islam menjadi landasan yang kuat yang akan mengantar manusia menggapai kebahagiaan hidup. Tanpa nilai islam, segala atribut duniawi, seperti harta, pangkat, IPTEK, dan keturunan tidak akan mampu mengantar manusia meraih kebahagiaan baik di dunia maupun akhirat. Beberapa strategi pembelajaran yang dikaitkan dengan penanaman nilai-nilai ajaran Islam yang dapat dilakukan dalam pembelajaran mata pelajaran matematika (Yasri, 2013), yaitu: 1) Selalu Menyebut Nama Allah, 2) Penggunaan Istilah, 3) Ilustrasi Visual, 4) Aplikasi atau Contoh-contoh, 5) Menyisipkan Ayat atau Hadits yang Relevan, 6) Penelusuran Sejarah, 7) Jaringan Topik, dan 8) Simbol Ayat-ayat Kauniah (Ayat-ayat Alam Semesta).

Berdasarkan penjelasan di atas, maka dapat diambil kesimpulan bahwa nilai-nilai keislaman dapat diintegrasikan dalam proses pembelajaran matematika, dimana nilai-nilai keislaman dimasukan dalam proses pembelajaran sehingga pembelajarannya bernuansa islami. Penanaman nilai-nilai islam tersebut juga dipadukan dalam pendekatan Realistic Mathematics Education (RME).

Pada tahun 1973, Freudental memperkenalkan suatu model baru dalam pembelajaran matematika yang dikenal dengan nama Realistic Mathematics Education atau istilah lain yaitu PMR 
(Pembelajaran Matematika Realistik). Realistic Mathematics Education (RME) awalnya dikembangkan di negeri Belanda (Melly dan Mimi, 2013). Menurut Saleh (2012) pendekatan pembelajaran matematika realistik adalah suatu pembelajaran berfokus pada masalah yang dapat dibayangkan siswa sebagai masalah dalam kehidupan nyata atau masalah dalam dunia mereka. Pendekatan Pembelajaran Matematika Realistik adalah salah satu pendekatan yang dikembangkan untuk semakin mendekatkan siswa dengan matematika (Prabowo dan Sidi, 2010). Siswa akan merasakan dekat dengan matematika karena siswa mengalami sendiri dalam kehidupan nyata sehingga belajar matematika akan terasa lebih bermakna. Dengan mengembangkan modul matematika yang diintegrasikan nilai-nilai keislaman melalui pendekatan Realistic Mathematics Education (RME) diharapkan dapat memecahkan masalah rendahnya hasil belajar matematika.

Penelitian yang dilaksanakan oleh Patmawati, Johar dan Zubaidah (2013) yang berjudul "Pengembangan Bahan Ajar Pembelajaran Matematika Berbasis Karakter melalui Pendekatan Realistik”. Penelitian ini adalah penelitian yang mengembangkan buku untuk panduan guru dan buku siswa dengan memperhatikan aspek lintasan belajar yang sesuai dengan perkembangan berfikir siswa di Sekolah Dasar (SD), kreativitas, dan demokrasi. Dalam penelitian ini, peneliti mencoba mengembangkan modul metematika terintegrasi nilai-nilai keislaman melalui pendekatan Realistic Mathematics Education (RME) yang akan diimplementasikan kepada siswa Madrasah Tsanawiyah (MTs).

\section{METODE PENELITIAN}

Penelitian ini dilaksanakan pada semester ganjil tahun ajaran 2016/2017 pada MTs AlMunawwarah Pekanbaru dan MTs Negeri Danau Bingkuang Kampar. Jenis penelitian yang digunakan dalam penelitian ini adalah penelitian pengembangan (Research and Development/R\&D). Research and Development adalah metode penelitian yang digunakan untuk menghasilkan produk tertentu, dan menguji keefektifan produk tersebut (Sugiyono, 2014). Sedangkan menurut Nana Syaodih (2015) penelitian dan pengembangan adalah suatu proses atau langkah-langkah untuk mengembangkan suatu produk baru atau menyempurnakan produk yang telah ada, yang dapat dipertanggungjawabkan. Penelitian pengembangan di bidang pendidikan merupakan suatu jenis penelitian yang bertujuan untuk menghasilkan produkproduk untuk kepentingan pendidikan atau pembelajaran berupa modul metematika terintegrasi nilai-nilai keislaman melalui pendekatan Realistic Mathematics Education (RME).

Model penelitian yang digunakan adalah model ADDIE. Salah satu model desain pembelajaran yang sifatnya lebih generik, ADDIE muncul pada tahun 1990-an yang dikembangkan oleh Reiser dan Mollenda. Salah satu fungsinya ADDIE yaitu menjadi pedoman dalam membangun perangkat dan infrastruktur program pelatihan yang efektif, dinamis dan mendukung. Model desain sistem pembelajaran yang memperlihatkan tahapan-tahapan dasar desain sistem pembelajaran yang sederhana dan mudah dipelajari adalah model ADDIE.

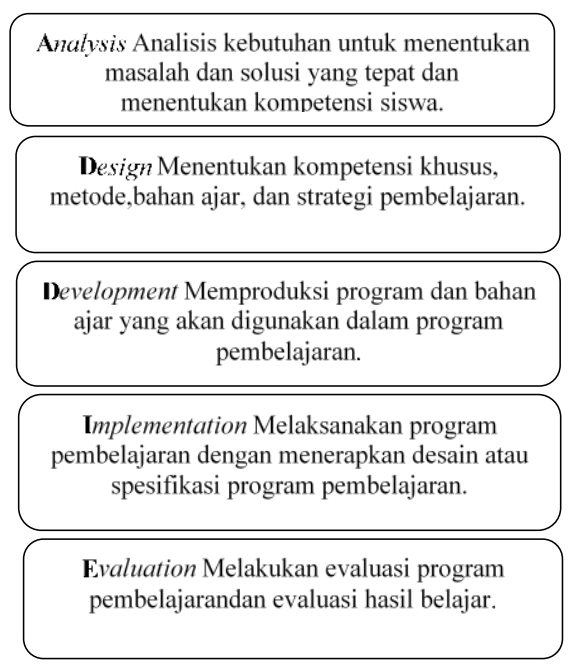

Gambar 1. Model Desain ADDIE

Jurnal Analisa Vol.4 No.1 Juni 2018 : 1-9 
Pengembangan Modul Matematika Terintegrasi Nilai-nilai

Keislaman melalui Pendekatan RME di Provinsi Riau

Model ini, sesuai dengan namanya, terdiri dari lima fase atau tahap utama, yaitu (A)nalysis, (D)esign, (D)evelopment, (I)mplementation, dan (E)valuation (Benny A. Pribadi, 2010). Kelima fase atau tahap dalam model ADDIE, perlu dilakukan secara sistemik dan sistematik.

Teknik pengumpulan data yang digunakan untuk mengevaluasi dan memvalidasi terhadap bahan ajar yang dikembangkan adalah angket dan tes. Teknik analisis data yang digunakan untuk mengolah data hasil pengembangan adalah teknik analisis deskriptif kualitatif dan teknik analisis kuantitatif. Analisis hasil uji validitas modul yang dikembangkan dapat dilakukan dengan beberapa langkah, yaitu memberikan skor jawaban dengan kriteria Sangat Baik (skor 5), Baik (skor 4), Cukup Baik (skor 3), Kurang Baik (skor 2), Tidak Baik (skor 1); memberikan nilai persentase dengan rumus (Sugiyono, 2014):

Tingkat validitas $=\frac{\text { skor diperoleh }}{\text { skor tertinggi }} \times 100 \%$ (1)

Kemudian menginterpretasikan data berdasarkan tabel berikut:

Tabel 1. Interpretasi Data Validitas Modul Terintegrasi Nilai-nilai Keislaman melalui Pendekatan $R M E$

\begin{tabular}{ccc}
\hline No & Interval & Kriteria \\
\hline $\mathbf{1}$ & $81-100$ & Sangat Valid \\
$\mathbf{2}$ & $61-80$ & Valid \\
$\mathbf{3}$ & $41-60$ & Cukup Valid \\
$\mathbf{4}$ & $21-40$ & Kurang Valid \\
$\mathbf{5}$ & $0-20$ & Tidak Valid \\
\hline
\end{tabular}

Sumber: Riduwan (2012)

Analisis hasil uji praktikalitas Modul yang dikembangkan dapat dilakukan dengan beberapa langkah, yaitu memberikan skor jawaban dengan kriteria Sangat Baik (skor 5), Baik (skor 4), Cukup Baik (skor 3), Kurang Baik (skor 2), Tidak Baik (skor 1); memberikan nilai persentase dengan rumus (Sugiyono, 2014):
Tingkat Praktikalitas

$$
=\frac{\text { skor yang diperoleh }}{\text { skor tertinggi }} \times 100 \%
$$

Kemudian menginterpretasian data berdasarkan tabel berikut:

Tabel 2. Interpretasi Data Praktikalitas

Modul Terintegrasi Nilai-nilai Keislaman melalui Pendekatan $R M E$

\begin{tabular}{ccc}
\hline No & Interval & Kriteria \\
\hline $\mathbf{1}$ & $81-100$ & Sangat Praktis \\
$\mathbf{2}$ & $61-80$ & Praktis \\
$\mathbf{3}$ & $41-60$ & Cukup Praktis \\
$\mathbf{4}$ & $21-40$ & Kurang Praktis \\
$\mathbf{5}$ & $0-20$ & Tidak Praktis \\
\hline \multicolumn{2}{l}{ Sumber: Riduwan (2012) }
\end{tabular}

\section{HASIL DAN PEMBAHASAN}

Pada tahap analysis dilakukan analisis kurikulum dan analisis kebutuhan. Modul akan digunakan oleh Siswa kelas VII MTs yang berusia kurang lebih 11-13 tahun. Pada usia 11 atau 12 tahun ke atas seorang remaja sudah dapat berpikir logis, logika remaja mulai berkembang dan digunakan (Suparno, 2001). Cara berpikir yang abstrak mulai dimengerti. Namun tidak semua siswa yang berada di tahap awal remaja ini mampu berpikir abstrak. RME menekankan pada keterampilan process of doing mathematics, berdiskusi, berkolaborasi, beragumentasi, dan mencari simpulan dengan teman sekelas. Model pembelajaran RME dapat dipandang sebagai model pembelajaran yang dilaksanakan agar kompetensi dasar dapat dicapai dengan cepat melalui proses belajar mandiri dan informal (Amin Suyitno, 2014). Berdasarkan pendapat tersebut pendekatan RME diharapkan dapat membantu peserta didik yang belum sepenuhnya bisa berpikir abstrak.

Selanjutnya tahap design yang merupakan tahapan untuk merancang modul matematika terintegrasi nilai-nilai keislaman melalui pendekatan RME serta komponen-komponen yang berkaitan dengan modul tersebut. Pada 
tahap design dilakukan beberapa desain yaitu mendesain cover yang merupakan unsur penting terhadap daya tarik siswa untuk membaca dan mencerminkan nilai-nilai keislaman, peta konsep, gambar pada awal Bab, kegiatan belajar, dan karikatur keislaman. Pada tahap ini juga menyusun instrumen penilaian modul yang digunakan sebagai alat ukur kualitas modul yang dikembangkan.

Setelah selesai pembuatan desain modul, kemudian modul yang dikembangkan di validasi oleh Validator ahli teknologi pendidikan dan ahli materi pembelajaran dengan menggunakan angket. Angket yang digunakan telah divalidasi oleh Validator ahli instrument seperti yang ditunjukkan oleh lembar validasi pada lampiran. Berdasarkan data pada lampiran tersebut, validator memberi nilai B yang berarti "dapat digunakan sedikit revisi”. Dengan demikian maka instrument angket tersebut sudah dapat digunakan untuk menilai modul. Setelah selesai, modul tersebut dinilai oleh ahli teknologi pendidikan dan ahli materi pembelajaran dengan menggunakan angket penilaian modul. Berikut hasil validitas oleh ahli teknologi pendidikan:

Tabel 3. Hasil Validitas oleh Ahli Teknologi Pendidikan

\begin{tabular}{|c|c|c|c|}
\hline No. & $\begin{array}{c}\text { Kriteria } \\
\text { Modul }\end{array}$ & $\begin{array}{c}\text { Nilai } \\
\text { Validasi }\end{array}$ & Kriteria \\
\hline $\mathbf{1}$ & $\begin{array}{l}\text { Penggunaan } \\
\text { huruf dan } \\
\text { tulisan }\end{array}$ & 89,52 & Valid \\
\hline 2 & Desain Modul & 80 & Valid \\
\hline 3 & $\begin{array}{l}\text { Penggunaan } \\
\text { gambar }\end{array}$ & 84,44 & Valid \\
\hline 4 & $\begin{array}{l}\text { Modul } \\
\text { berpenampilan } \\
\text { menarik }\end{array}$ & 84,44 & Valid \\
\hline & Rata-rata & 85,19 & Valid \\
\hline
\end{tabular}

Berdasarkan Tabel 3, jelas terlihat bahwa persentase keseluruhan dari penilaian oleh kedua ahli teknologi pendidikan adalah
Sangat Valid, karena berada pada rentang 81 sampai 100, sehingga modul pembelajaran sangat praktis. Namun komentar dan saran dari ahli teknologi pendidikan dijadikan bahan perbaikan untuk menyempurnakan modul pembelajaran yakni perbaiki kecerahan warna cover, karikatur yang islami dan sesuaikan penempatan gambar. Berikut hasil validitas oleh ahli materi pembelajaran:

Tabel 4. Hasil Validitas oleh Ahli materi Pembelajaran

\begin{tabular}{|c|c|c|c|c|}
\hline No & $\begin{array}{l}\text { Variabel } \\
\text { Validitas }\end{array}$ & Kode & Nilai & $\begin{array}{c}\text { Kriter } \\
\text { ia }\end{array}$ \\
\hline \multirow[t]{4}{*}{1} & Syarat & A & 93 & Sangat \\
\hline & Didaktif & & & Valid \\
\hline & & B & 83 & Valid \\
\hline & & $\mathrm{C}$ & 89 & Valid \\
\hline \multirow[t]{6}{*}{2} & Syarat & $\mathrm{A}$ & 82 & Valid \\
\hline & Konstruktif & B & 87 & Valid \\
\hline & & $\mathrm{C}$ & 80 & Valid \\
\hline & & $\mathrm{D}$ & 73 & Valid \\
\hline & & $\mathrm{E}$ & 10 & Sangat \\
\hline & & & o & Valid \\
\hline \multirow[t]{7}{*}{$\mathbf{3}$} & Syarat & A & 87 & Valid \\
\hline & Pendekatan & B & 73 & Valid \\
\hline & RME & $\mathrm{C}$ & 10 & Sangat \\
\hline & & & o & Valid \\
\hline & & $\mathrm{D}$ & 87 & Valid \\
\hline & & $\mathrm{E}$ & 93 & Sangat \\
\hline & & & & Valid \\
\hline \multirow[t]{5}{*}{4} & Syarat & A & 83 & Valid \\
\hline & Terintegrasi & & & \\
\hline & nilai-nilai & B & 83 & Valid \\
\hline & Keislaman & & & \\
\hline & Rata-rata & & 86 & $\begin{array}{l}\text { Sangat } \\
\text { Valid }\end{array}$ \\
\hline
\end{tabular}

Berdasarkan Tabel 4, jelas terlihat bahwa persentase keseluruhan dari penilaian kedua ahli materi pembelajaran adalah sangat valid karena berada pada rentang 81 - 100 .

Saran perbaikan yang diberikan ahli materi pembelajaran antara lain adalah perbaiki cover, beri intro untuk materi segitiga/ ahli matematika islam pada materi segitiga, beri nama segitiga, seragamkan animasi, instruksi 
Pengembangan Modul Matematika Terintegrasi Nilai-nilai Keislaman melalui Pendekatan RME di Provinsi Riau

diperjelas, tambah referensi, perbaiki penggunaan konteks nyata dan penulisan huruf harus konsisten, tampilan gambar yang jelas dan menarik, contoh segitiga bias dengan 3 titik dalam huruf hijaiyah serta tambahkan konteks nyata pada awal diintegrasikan dengan nilai-nilai keislaman. Berikut hasil penilaian secara keseluruhan:

Tabel 5. Hasil Validitas Secara Keseluruhan

\begin{tabular}{ccc}
\hline No. & $\begin{array}{c}\text { Variabel } \\
\text { Validitas } \\
\text { Modul }\end{array}$ & $\begin{array}{c}\text { Persentasi } \\
\text { keidealan }\end{array}$ \\
\hline $\mathbf{1}$ & $\begin{array}{c}\text { Ahli Teknologi } \\
\text { Pendidikan }\end{array}$ & 85,19 \\
$\mathbf{2}$ & $\begin{array}{c}\text { Ahli Materi } \\
\text { Pembelajaran } \\
\text { Rata-rata }\end{array}$ & 86,42 \\
& $\begin{array}{c}\mathbf{8 6}, 58 \\
\text { (Sangat Valid) }\end{array}$ \\
\hline
\end{tabular}

Berdasarkan Tabel 5, jelas terlihat bahwa persentase keseluruhan dari penilaian para ahli adalah valid, karena berada pada rentang 81 - 100, sehingga modul pembelajaran sudah Sangat layak untuk digunakan. Namun saran dan komentar dari ahli dijadikan bahan perbaikan dalam penyempurnaan modul ini.

Setelah modul matematika yang dikembangkan divalidasi oleh validator, selanjutnya modul matematika yang dikembangkan diujicobakan. Uji coba dilakukan di kelas VII MTs Al-Munawwarah Pekanbaru yang berjumlah 34 siswa dan kelas VII MTs Negeri Danau Bingkuang Kampar berjumlah 21 siswa. Hasil penilaian uji praktikalitas pada saat uji coba dipaparkan dalam Tabel 6 sebagai berikut.

Tabel 6. Persentase Praktikalitas Pada Saat Uji Coba

\begin{tabular}{cccc}
\hline No & Variabel & Nilai & Kriteria \\
& Praktikalitas & Praktikalitas & \\
\hline 1. & Minat siswa & 85 & Praktis \\
& dan tampilan & & \\
& Modul & & \\
2. & Penggunaan & 82,84 & Praktis \\
& Modul & & \\
\hline
\end{tabular}

\begin{tabular}{cccc} 
3. & Hasil Belajar & 83,33 & Praktis \\
& dan Materi & & \\
4. & Waktu & 86,91 & Praktis \\
5. & Evaluasi & 87,64 & Praktis \\
& Rata-rata & $\mathbf{8 4 , 1 4}$ & Praktis \\
\hline
\end{tabular}

Berdasarkan Tabel 6, jelas terlihat bahwa persentase keseluruhan dari penilaian siswa pada uji coba kelompok terbatas adalah sangat praktis, karena berada pada rentang 81 - 100, sehingga modul pembelajaran sedikit memerlukan revisi. Namun saran dan komentar dari siswa dijadikan bahan pertimbangan dalam penyempurnaan modul ini yakni ada kesalahan pengetikan rumus, ketidaksesuaian gambar dengan keterangan, nama pada segitiga ada yang tidak sesuai dan soal pada tes formatif masih kurang jelas sehingga tidak bisa di jawab.

Tahap terakhir adalah evaluation (evaluasi). Pada tahap ini dilakukan revisi terhadap modul yang telah dikembangkan. Perbaikan dilakukan berdasarkan hasil penilaian dari validator maupun siswa. semua saran perbaikan yang diberikan terhadap modul yang dikembangkan direvisi dengan baik.

Penelitian pengembangan modul terintegrasi nilai-nilai keislaman melalui pendekatan $R M E$ ini tidak terlepas dari beberapa keterbatasan. Adapun keterbatasan tersebut antara lain.

1. Modul matematika terintegrasi nilai-nilai keislaman melalui pendekatan RME hanya di uji pada satu kelas saja pada masingmasing sekolah (yakni pada dua sekolah yang diteliti). Karena keterbatasan waktu dan biaya, peneliti tidak dapat menguji pada lapangan yang lebih luas.

2. Uji coba keefektifan modul matematika terintegrasi nilai-nilai keislaman melalui pendekatan RME dilakukan tanpa kelas pembanding.

3. Materi dalam modul hanya sebatas bab segitiga.

4. Integrasi nilai-nilai keislaman pada materi segitiga terbatas pada bagian tertentu. 
5. Belajar sendiri dengan modul memerlukan disiplin. Siswa harus sanggup mengatur waktu, memaksakan diri untuk belajar dan kuat terhadap godaan teman untuk bermain.

6. Siswa yang telah terbiasa menerima pelajaran dari guru, kebanyakan cendrung menjadi pasif dan akan kesulitan beralih kepada cara baru yang menuntut aktivitas sebagai dasar utama dalam belajar.

\section{KESIMPULAN}

Berdasarkan hasil penelitian yang telah diuraikan pada bab sebelumnya maka dapat diambil kesimpulan bahwa telah dihasilkan bahan ajar berupa modul matematika terintegrasi nilai-nilai keislaman melalui pendekatan Realistic Mathematic Education (RME) pada materi segitiga yang valid, praktis dan efektif dalam memfasilitasi kemampuan matematika siswa.

Berdasarkan temuan yang diperoleh dalam penelitian ini, maka dikemukakan saransaran sebagai berikut.

1. Modul yang telah dihasilkan ini telah valid, praktis dan efektif maka modul ini dapat digunakan dalam pembelajaran pada materi segitiga.

2. Penggunaan modul ini akan lebih produktif jika disertakan alat peraga sederhana guna mempermudah bagi siswa dalam menemukan konsep rumus keliling dan luas bangun datar segitiga.

3. Modul matematika terintegrasi nilai-nilai keislaman melalui pendekatan Realistic Mathematic Education (RME) ini dikembangkan lebih lanjut dan mendalam dengan melakukan eksperimen menggunakan kelas pembanding agar kualitas modul ini lebih teruji keefektifannya.

4. Bagi peneliti selanjutnya hendaklah mengembangkan modul matematika terintegrasi nilai-nilai keislaman melalui pendekatan Realistic Mathematic Education (RME) dengan materi yang berbeda dan pada materi yang lebih luas lagi.

\section{UCAPAN TERIMA KASIH}

Terima kasih kami ucapkan kepada Lembaga Penelitian dan Pengabdian Masyarakat (LPPM) UIN Sultan Syarif Kasim Riau

\section{DAFTAR PUSTAKA}

Andriani, Melly dan Mimi Haryani. (2013). Pembelajaran Matematika SD/MI, Pekanbaru: Benteng Median.

Hartati,dkk (2017). Kemampuan Pemecahan Masalah Matematika Ditinjau dari Kreativitas dan Kecerdasan Emosional. Jurnal Analisa Vol.3 No.2 Desember 2017 :106-115

Patmawati, D., Johar, R., Zubaidah, T. (2013). Pengembangan Bahan Ajar Pembelajaran Matematika Berbasis Karakter melalui Pendekatan Realistik. Jurnal Pendidikan Matematika PARADIKMA, 5(2), 1-13

Prabowo, Agus dan Pramono Sidi. (2010). Potensi PMRI sebagai Inovasi dalam Pembelajaran Matematika. Program Studi Matematika Universitas Jenderal Sudirman : Universitas Terbuka.

Pribadi, Benny A. (2010). Model Desain Sistem Pembelajaran. Jakarta : Rineka Cipta.

Rahayu Sri Waskitoningtyas. (2016). Analisis Kesulitan belajar matematika siswa kelas V sekolah dasar kota Balikpapan pada materi satuan waktu tahun ajaran 2015/2016, Jurnal Ilmiah Pendidikan Matematika, 5(1), 24-32

Riduwan. (2012). Belajar Mudah Penelitian untuk Guru, Karyawan dan Peneliti Pemula. Bandung: Alfabeta. 
Saleh, Muhammad. (2012). Pembelajaran Kooperatif dengan Pendekatan Pembelajaran Matematika Realisti

(PMR), Jurnal Pendidikan Serambi Ilmu, 13 (2).

Syaodih, Nana. (2015). Metode Penelitian Pendidikan. Bandung : PT Remaja Rosdakarya Offset.

Somayasa, Wayan., Natajaya, Nyoman., Candiasa, Made. (2013). Pengembangan Modul Matematika Realistik disertai Asesmen Otentik Untuk Meningkatkan Hasil Belajar Matematika Peserta Didik Kelas $\mathrm{X}$ di SMK NEGERI 3 SINGARAJA, Jurnal Ilmiah Pendidikan dan Pembelajaran GaneshaProgram Studi Penelitian dan Evaluasi Pendidikan, 3(1), 1-12

Sugiyono. (2014). Metode Penelitian Kuantitatif Kualitatif dan R\&D. Bandung: Alfabeta.

Suparno, Paul. (2001). Teori Perkembangan Kognitif Jean Piaget, Yogyakarta: Kanisius.

Suyitno, Amin. (2014). Dasar-Dasar Dan Proses Pembelajaran Matematika I, Program Studi Pendidikan Matematika FMIPA UNNES.

S, Nasution. (2011). Berbagai Pendekatan dalam Proses Belajar Mengajar. Jakarta: Bumi Aksara.

Wena, Made. (2011). Strategi Pembelajaran Inovatif Kontemporer. Jakarta: Bumi Aksara.

Yasri. Strategi Pembelajaran Matematika Bernuansa Islami (2013).. Tersedia:http://bdkpadang.kemenag.go.i d). diakses 22 Maret 2015. 